\title{
Power and Architecture in Portuguese Fascism: Political and Artistic Control and Resistance
}

\author{
Joana Brites \\ University of Coimbra, Coimbra, Portugal
}

\begin{abstract}
This paper analyses the system of artistic and ideological conditioning that architects were subject to during the Portuguese fascism, the so-called "New State", the longest western European dictatorship of the previous century, that lasted from 1933 to 1974, under the uninterrupted leadership of António de Oliveira Salazar until 1968. After a concise exposition of the importance of a major public work campaign to the regime affirmation as well as the aesthetic discourse promoted in its architecture, the standard course of a building project evaluation will be described. Crossing varied legislation and taking into consideration the results of a thorough examination to more than one hundred processes of architectural plans approval, the interaction of the various decision-making bodies will illustrate the existence of an efficient apparatus which progressively depurate designs. Prevention and repression of artistic deviation will be demonstrated. Furthermore, the development and importance of self-censorship will be highlighted. Secondly, a characterization of the atmosphere of ideological surveillance and dissident's oppression will be provided. Architects' participation in opposition's initiatives and strategies will be portrayed. As a conclusion, New State practice of a negotiation and inclusion (both artistic and ideological) tactic in the architectural field will be underlined.
\end{abstract}

Keywords: New State, fascism, architecture, control, opposition

\section{Architecture in the Affirmation of the New State}

The major public works campaign launched by "Estado Novo" ("New State", 1933-1974) - the Portuguese fascism ${ }^{1}$ that emerged from the military dictatorship established with the coup d'etat of May 28, 1926 (Rosas, 1993) - brought into being the first modern network of modern structures and infrastructures of the country. The initiative was a common strategy in response to conjunctural events (the Wall Street Crash of 1929 and the Great Depression) and structural turns (the reshape of socio-economic regulation and increased State intervention in the economy), which characterized the international scene at the time. It was enabled by the rebalancing of public accounts, achieved by the combination of increased revenues (tax reform, extraordinary taxation, new recipes) with expenses contraction (limitation of the social costs and an enhanced budget discipline). Led by engineers - elite who ruled over the decisive Ministry of Public Works and

Joana Brites, Invited Assistant Professor, Department of History, European Studies, Archaeology and Arts of the Faculty of Arts and Humanities, University of Coimbra.

1 There is no consensus on the classification of the "Estado Novo" (New State) as fascism in Portuguese and international historiography. Since it is beyond the scope of this article, for a further discussion of this subject see: Nolte, 1969; O Fascismo em Portugal. Actas do Colóquio, 1982; O Estado Novo. Das Origens Ao Fim Da Autarcia (1926-1959), 1987; Cruz, 1988; Collotti, 1992; Pinto, 1992; Torgal, 1994; Lucena, 1995; Linz, 2000; Medina, 2000; Rosas, 2001; Nunes, 2002. 
Communications (Madureira, 2002, p. 111), reorganized in 1932-it actively engaged a recent formed generation of architects whose opportunities of work were rare and whose specific expertise was still far from be socially recognised and required in the construction field.

If the architectonic landscape of Portugal was indeed changing without precedents, this shift was greatly magnified by the propaganda discourse. These fresh buildings were presented as the visual translation of the regime narrative, one of effectiveness, order in economy and social life, and rebirth of the true values of the nation. "To a new era if that era has greatness and prospect, must correspond a new art", proclaimed Ferro $(1949, \text { p. } 22)^{2}$, a charismatic writer and journalist previously actively involved with the Futurist movement, appointed director of the Secretariat of National Propaganda created in 1933. Architecture was absorbed by the Manichean logic of the official statements of the Head of Government, António de Oliveira Salazar. The contrast with the previous political order was systematically acclaimed. The difference promoted in the artistic panorama was another to illustrate the allegedly "salvation" and "revolution" (Salazar, 1935, p. 318) ${ }^{3}$ in progress: The new national history chapter was literally being erected on the top of more than a century of supposedly monarchical and republican liberalism decadence.

Even though the New State never prescribed with accuracy the type of architecture desired, it did know exactly what it did not want: The International Style, the so-called "boxes" (Costa, 1944, January 26, p. 3) with a flat roof, plane surfaces stripped from any ornament and horizontal rows of windows forming a grid. This was regarded as unsuited to the Portuguese climate and character, stateless, and with the dangerous capacity to disaggregate the soul of the country.

In spite of the relative heterogeneity of New State architecture, a core teleological narrative guided the logic of projects' evaluation. It can be detected, not only in the speeches and official publications of the regime, but also in the specialized (although limited) press dedicated to architecture critique. It is a kind of refrain, widely spread but never quite defined regarding its meaning or practice: the quest for a national modern, a style at the same time contemporary and suited to the locality and/or specificity of the country (Brites, 2014a). It was achieved by literally wrapping up the "box" buildings with historicists elements (stylized versions of various styles from classic to baroque) or a regional flavour (chimneys, pinwheels, porches, iron works and other traditional elements, often invented, actually $)^{5}$.

\section{A Powerful Instrument Must Be Aesthetically Controlled}

To assure the elected "national modern" aesthetics, prevention and repression of artistic deviation were of paramount importance. Therefore, from the very outset, an impressive legal web was set up for choosing architects and for approving and overseeing public works projects. State's conditioning action had two interconnected vectors. One committed to the technical sphere (analysis and guidance of building designs), supported by legislation enacted by the Ministry of Public Works and Communications. The second related with the financial partial or full contribution from the Government (in any field, in this case a construction contract), subjected to a thorough process of regulation established by the Finance Ministry. One needs, thus, to

\footnotetext{
2 Translation by the author.

3 Translation by the author.

4 Translation by the author.

${ }^{5}$ For a further discussion of the architecture of the New State see: Portas, 1973; França, 1974; Pereira \& Fernandes, 1981; Almeida \& Fernandes, 1986; Fernandez, 1988; Acciaiuoli, 1991; Pereira, 1997; Tostões, 1997; Pernes, 1999; Alçada \& Grilo, 1999; Almeida, 2002; Fernandes, 2003; Tostões, 2004; Rosmaninho, 2006; Tostões, 2009; Tostões, 2015.
} 
cross examine dozens of decrees from (especially) both these entities to understand how public architecture was supervised. Indeed, there is not a unique official order that determines architecture control, which in fact was denied by Oliveira Salazar himself (Entrevistas de António Ferro a Salazar, 2013, p. 135). The National Assembly and the President of the Republic found themselves drained of powers. As a result New State constituted not only a "real dictatorship of the Executive", but rather a "personal dictatorship of the President of the Ministers' Council” (Rosas, 1992, pp. 121-122) ${ }^{6}$. The dictator was, as António Costa Pinto points out, "a master in manipulating a rational-legal perverted legitimacy", extending "its careful assessment (...) practically to the entire legislative output, far beyond the control needs common in other dictatorial political systems" (Pinto, 2001, p. 1057) ${ }^{7}$. Not by accident, rules and precepts are highly dispersed and disseminated, configuring the classic Foucault's model of control exercise: far from linear, solid and unidirectional, it circulates, depends on a chain and functions through a network of agents (Foucault, 1998, p. 183). However, after gathering and combining all the directives, the journey that every design had to take emerges with a transparency characteristic of the Weberian pyramid of bureaucracy (Weber, 1978). This does not mean that decisions were bullet-proof to factors of personal nature. Moreover, face-to-face conversations or direct phone calls in order to influence choices of taste or authorship, today very hard to restore, should not be disregarded. Nevertheless, an extensive exam of the evaluation process of more than one hundred public building projects (Brites, 2014b), led to the belief that architecture restraint is best explained by a rational, efficient and effective legal gear than by secretiveness or disguised agendas.

Specialized committees were appointed, within the organigram of the Ministry of Public Works and Communications, to manage and supervise the construction of each one of the various public architecture typologies of New State (mainly education structures for every level; prisons; hospitals; State's bank agencies; postal, telegraph, and telephone buildings). If the chief-architect of each committee was not responsible for the design, this task would be outsourced. Although the cost of a building design determined the compulsory opening of a public competition ${ }^{8}$, in the overwhelming majority of cases authors were handpicked by the cream of the Ministry of Public Works and Communications rulers and personally invited to work. What represented a juridical exception - the possibility given to the Minister to outpace this requirement when and if properly justified ${ }^{9}$ - became the ordinary procedure, and even the necessary substantiation was uniformed in about two sentences (the urgency of the acquisition and the quality of the proposed artist).

Once the first version of a building design was finished and presented to the respective Committee, the evaluation path began. The number of stops-i.e., pronouncements of administrative spheres with decision-making capacity in the architectural field-depended on the construction expenses foreseen ${ }^{10}$. These were tabulated according to the importance attributed to the typology in question ${ }^{11}$. Therefore, an effort to decrease costs with the purpose of avoiding additional judgements, was forbidden and, if attempted, neutralized

\footnotetext{
6 Translation by the author.

7 Translation by the author.

${ }^{8}$ Law Decree n. ${ }^{\circ} 27$ 563, Diário do Governo [Government Bulletin], 1st series, n. ${ }^{\circ}$ 60, Lisbon, 13 March 1937, p. 216.

9 Law Decree n. ${ }^{\circ} 27$ 563, Diário do Governo [Government Bulletin], 1st series, n. ${ }^{\circ}$ 60, Lisbon, 13th March 1937, p. 216.

$10{ }^{1}$ Decree n. ${ }^{\circ} 19$ 881, Diário do Governo [Government Bulletin], 1st series, n. ${ }^{\circ}$ 135, Lisbon, 12th June 1931, pp. 1141-1142. Updated by the following: Law Decree n. ${ }^{\circ} 36$ 353, Diário do Governo [Government Bulletin], 1st series, n. ${ }^{\circ}$ 137, Lisbon, 17th June 1947, p. 537 and Law Decree n. ${ }^{\circ}$ 55/70, 13th February 1970, Colecção Oficial de Legislação Portuguesa [Official Collection of Portuguese Legislation], 1st semester of 1970, Lisbon, 1973, p. 193.

11 Directive by the Minister of Public Works: "Instructions for prior assessment of the approximate cost of public buildings", 20th December, 1956. Historical Archive of Caixa Geral de Depósitos, Works plans-box n. ${ }^{\circ} 1$, file n. ${ }^{\circ} 3$.
} 
by an immediately order issued to guarantee the respect for the stipulated amount per $\mathrm{m}^{2}$ for that category of edifice $^{12}$.

Taking into consideration the high sum of money required by the construction of the above mentioned public structures, the standard course of a regular building project comprehended three main analysis entities. The first and only one outside the ministerial grid was the city/town council to where the building was planned. Although its responsibility was reduced to a simple confirmation that the alignment did not collided with the urbanization plan ${ }^{13}$, the local government rarely resisted to interfere in the aesthetics of the facades, granting approval conditional on a stylistic changing, manipulating the regional press or by offering suggestions for elevations. The subject matter scarcely distanced from the appeal to an adaptation of the design to the local environment and, as also observed in central government experts' critics, it reveals a concept of architecture exclusively based on the exterior.

When accepted as satisfactory by the city/town council, the design was sent to the so-called "Review Committee" of the General Directorate of National Buildings and Monuments (DGEMN) ${ }^{14}$, a major body still created during the military dictatorship (1929) and then incorporated in the Ministry of Public Works and Communications. This review was then subjected to the superior examination of the director-general of DGEMN, who could reinforce, alter or add comments. The third and final step in the fabric of this Ministry corresponded to the prestigious High Council of Public Works, whose scrupulous assessment (mandatory for the more expensive buildings; optional and dependent on the minister's will on all others) could only be outstripped by the minister himself $\mathrm{f}^{15}$.

Alongside these three circles (which opinion could be complemented with advice from other boards within the same Ministry, mostly related with urbanism ${ }^{16}$ ), another Ministry — the National Education one-was called to participate in particular circumstances. If the new construction's implantation coincided with buffer zones of national monuments or buildings of public interest a mandatory pronouncement should analyse the impact of the architectural style on the surroundings ${ }^{17}$. One might suppose this situation was rather rare. On the contrary, the State normally chose to locate its key public buildings in town/city centres, resulting in the demolition of pre-existing properties and in the selection of prominent areas hardly clear of those two categories of protected structures.

The usual route of a building project above described could take years, thus, its linearity is merely apparent. In fact, the design must take this path in its preliminary phase and then all over again in the final

\footnotetext{
${ }^{12}$ As an example see: Pronouncement of the Review Committee about the design of a bank agency of Caixa Geral de Depósitos for Vila Real, Lisbon, 23th February 1957. Historical Archive of Caixa Geral de Depósitos, Construction and repair of buildings: agencies in districts-box n. ${ }^{\circ} 30$, file n. ${ }^{\circ} 196$ (Vila Real); Pronouncement of the Review Committee about the design of a bank agency of Caixa Geral de Depósitos for Espinho, Lisbon, 15th February 1958. Historical Archive of Caixa Geral de Depósitos, Construction and repair of buildings: agencies outside districts- box n. ${ }^{\circ} 12$, file . $^{\circ} 87$ (Espinho).

${ }^{13}$ Directive by the Minister of Public Works, Diário do Governo [Government Bulletin], 1st series, n. ${ }^{\circ}$ 255, Lisbon, 2nd November 1940, p. 1258; Law Decree n. ${ }^{\circ} 38$ 382, Diário do Governo [Government Bulletin], 1st series, n. ${ }^{\circ}$ 166, Lisbon, 7th August 1951, p. 718.

14 Decree n. ${ }^{\mathrm{o}} 19$ 881, Diário do Governo [Government Bulletin], 1st series, n. ${ }^{\circ}$ 135, Lisbon, 12th June 1931, pp. 1141-1142.

${ }^{15}$ Created by Decree n. ${ }^{\circ} 16$ 791, Diário do Governo [Government Bulletin], 1st series, n. ${ }^{\circ}$ 97, Lisbon, 30th April 1929, pp. 1055-1057.

${ }^{16}$ Mainly: the General Directorate of Urbanism Services (DGSU), included in the Ministry of Public Works and Communications and created by Law Decree n. ${ }^{\circ} 34$ 337, 27th December 1944, Colecção Oficial de Legislação Portuguesa [Official Collection of Portuguese Legislation], 2nd semester of 1944, Lisbon, 1954, pp. 583-584. Furthermore, the cooperation of the National Roads Authority was determined by a ministerial order of 8th June, 1956.

${ }_{17}$ Decree n.o 38 888, 29th August 1952, Colecção Oficial de Legislação Portuguesa [Official Collection of Portuguese Legislation], 2nd semester of 1952, Lisbon, 1956, p. 125.
} 
version developed $^{18}$. If, at any time, one of those evaluation spheres made a negative remark, the design had to be reformulated and restart its journey. In the mentioned study conducted to more than one hundred buildings construction processes (Brites, 2014b), no case of a design completely approved at the first or even second time by all the administrative bodies was detected. Architects could be compelled to present more than seven different proposals and if resistance in accepting the "recommendations" was perceived the future career of this architect could be seriously affected. A directive determined that:

when more than three projects by the same author presented to the same department are rejected the case will be brought to the attention of the minister of Public Works and Communications, which will order its exam by a committee composed of the secretary-general of the Ministry, the managing director or director-general of the respective department and a member of the High Council of Public Works chosen by the minister. This committee shall inform whether or not the author in question should be excluded from the list of those who can present projects in the department in question ${ }^{19}$.

Consequently, self-censorship represented a powerful mechanism exploited by the regime to reduce dissident artistic behaviour. Furthermore, an efficient method of architecture critique was adopted towards keeping architects, no matter their ideological or aesthetic position, in the New State's apparatus. Regardless the importance of the ministerial entity, not a single pronouncement purely rejected a design. Every time, the decision laid on a recommendation for a more or less strictly guided and conclusive reformulation, despite frequently expressed in ambiguous words. A procedure repeated until exhaustion. The evaluation hierarchy was a machine for progressively expurgate and depurate designs until they match New State's desired image and cultural policy, the entitled "Spirit Politics", which accompanied the very evolution of the regime internally and its international context ${ }^{20}$. In other words, independently of the input (an artist with specific beliefs and taste preferences) the output could be entirely standardized, in the suitable degree and with the margin of tolerance allowed by decision-making ranks involved. A subversive architectural attempt would hardly survive the extensive and multifaceted screening put in place.

Finally, a light must be shed on the role of the dictator himself, António de Oliveira Salazar. His omnipresence disguised as "invisibility" (Gil, 1995, p. 7) ${ }^{21}$-one of the particular features of Portuguese fascism: the contrived and propagandized image of a discreet leader, adverse to public exposure, willing to abnegate his personal life for the sake of the restoration of the nation — can be also demonstrated on the subject of architecture control. When the sifted design was at last approved, the contract for the building construction (accompanied by the architectural plan), as it required allocation of financial resources of the central government budget, could only be signed after the draft was approved by the Ministers' Council and, then, ratified by the Court of Auditors ${ }^{22}$. This last body, responsible for the supreme financial oversight of the State, belonged to the inner trust circle of the regime since all their members were lifetime appointed by the minister of Finance $^{23}$ (Salazar cumulatively occupied this office until 1940). In its turn, the Ministers' Council fictitious

\footnotetext{
${ }^{18}$ General Directive n. ${ }^{\circ}$ 15, addressed by the head of the General Secretariat of the Ministry of Public Works to all services of this Ministry, 9th February 1945. Historical Archive of Caixa Geral de Depósitos, Construction and repair of buildings: General Directives-box n. ${ }^{\circ} 1$, file n. ${ }^{\circ} 5$.

${ }^{19}$ Law Decree n. 23 511, Diário do Governo [Government Bulletin], 1st series, n. ${ }^{\circ}$ 22, Lisbon, 26th January 1934, pp. 147-148. Translation by the author.

${ }^{20}$ For a further discussion of the cultural policy of the regime see: Ó, 1999; Melo, 2001; Alves, 2013.

21 Translation by the author.

22 Decree n..$^{\circ} 27$ 563, Diário do Governo [Government Bulletin], 1st series, n. ${ }^{\circ} 60$, Lisbon, $13^{\text {th }}$ March 1937, p. 216.

${ }^{23}$ Decree n. $^{\text {o } 22} 257$, 25th February 1933, Colecção Oficial de Legislação Portuguesa [Official Collection of Portuguese Legislation], 1st semester of 1933, Lisbon, 1941, p. 188.
} 
nature (in reality an over-concentration of power in the hands of Oliveira Salazar) would be confirmed by a 1957 decree determining that "the Council of Ministers may delegate all or part of its competence in the President's Council" ${ }^{24}$. Therefore, the dictator acted as the ultimate safety valve before a contract award, examining the final architectural plan whose development process he had monitored from the beginning through the minister of Public Works.

However, it would be an overstatement to argue that the head of the New State personally controlled architecture or stipulated elevations with detail. His know-how in this discipline and ability to discuss it with detail was limited and his rare official recommendations on this subject denoted vagueness and paternalism. An exemplary statement could be quoted. In a typical fabricated modesty, Salazar declared "far be it from me the ridiculous pretension to create a style or to inspire a style. I would be pleased if the constructions to be carried out are simply Portuguese and beautiful..." (Entrevistas de António Ferro a Salazar, 2013, p. 135) ${ }^{25}$. Moreover, contradicting the result of a tuned architectural plan submitted to this evaluation chain would question the precise system that he conceived. It should function, in his own words, with a "machine" precision (Entrevistas de António Ferro a Salazar, 2013, p. 26) ${ }^{26}$.

On the other hand, there is no doubt that Salazar defined overall guidelines, conditioned the process of evaluation and its agents, raising doubts, forcing to rethink decisions, demanding explanations, assuring, at bottom, the opportunity and legitimacy of an ulterior damage control. The bureaucratic apparatus for architecture conditioning analysed could easily — if there was a clear one - be use to impose a stylistic diktat. Easily, one might argue. Under these circumstances, the dictator power remained latent (constant but not necessarily seen in action) which is, in fact, one of the most efficient and economic forms of coercion (Foucault, 1979, p. 201-202). Once again, self-censorship, not only by architects, but also by individuals with decision-making capacity in the architectural field was fostered. As Foucault rightly emphasizes, "the perfection of power should tend to render its actual exercise unnecessary" (Foucault, 1979, p. 201).

\section{Ideological Surveillance and Resistance}

The conditioning system of architects was not reduced to their designs. Their thoughts and actions had to be monitored as well. As any citizen, they were subjected to the global strategy of New State for a totalitarian intervention in the nation. Benito Mussolini's motto "Everything in the State, nothing against the State, nothing outside the State" corresponded to the Salazarian maxim "All for the nation, nothing against the nation" (Salazar, 1935, p. 34) ${ }^{27}$. Activities from leisure to work were arranged. A "new man" (Rosas, 2001) would be reshaped through the creation of fascist organizations according to age and gender. The corporative structure implemented also encompassed the socio-professional group in question, since the compulsory creation of the Architects Union in $1933^{28}$. While affiliation was not mandatory, it was strongly encouraged ${ }^{29}$ and with a 1954 decree became a required condition to design new public works ${ }^{30}$.

\footnotetext{
${ }^{24}$ Law Decree n. ${ }^{\circ} 41$ 375, Diário do Governo [Government Bulletin], 1st series, n. ${ }^{\circ}$ 262, Lisbon, 19th November 1957, pp. 1126-1127. Translation by the author.

25 Translation by the author.

26 Translation by the author.

27 Translation by the author.

${ }^{28}$ About the history of the Portuguese Architects Union see: Gomes, 2000 and Isabel, 2002.

${ }^{29}$ General Directive n. ${ }^{\circ} 26$ from the General Directorate of National Buildings and Monuments (DGEMN), 25 th April 1941. Historical Archive of Caixa Geral de Depósitos, Construction and repair of buildings: General Directives- box n..$^{\circ} 1$, file n. $^{\circ} 1$.

${ }^{30}$ Law Decree n. ${ }^{\circ} 39$ 847, Diário do Governo [Government Bulletin], 1st series, n. ${ }^{\circ}$ 224, Lisbon, 8th October 1954, p. 1186.
} 
Parallel liberty restriction of expression and association, as well as repression measures were assured essentially by the following devices: legal control of associations' formation and their boards composition; directorates responsible for censorship services; coordination of advertising and information services; Secretariat of National Propaganda/National Information, Popular Culture and Tourism Secretariat/State Department of Information and Tourism; public security forces in coordination and interaction with a centralized and specialized body of surveillance and political repression (a political police, named PVDE/PIDE/DGS ${ }^{31}$ ); establishment of special courts and generalization of methods of physical and psychological torture; political prisons and concentration camps, officially called "penal colonies", where those arrested could remain for years without a formal charge or trial ${ }^{32}$.

As part of the intellectual sector of society (a fringe, thus the illiteracy rate for citizens older than 7 years in Portugal still reached $40.4 \%$ in $1950^{33}$ ), architects were an elite closely watched. Dissidents' monitoring and subduing comprehend diversified measures that differed in scale of severity, from correspondence violation to actual prison time for architects who committed what was considered a "political crime", judged by a perverted justice system. Architecture studios - which often functioned as places where "subversive" and "opposition" pamphlets were stored, reproduced, and distributed - were searched (without the need of a warrant) by the political police. If anything problematic was found, arrests and interrogations would follow.

In order to understand the permanent climate of fear is imperative to highlight the omnipresence of informants, citizens that voluntarily gave crucial (not necessarily accurate) data to the political police. In the archives of the Portuguese fascist political police, one can find, amongst hundreds, reports about architects' conversations in cafes, on conferences (examining if the architect criticizes the regime and how the audience reacted) and detailed accounts on the general assembly reunions of the Architects Union. In moments seen as especially problematic and, therefore, excellent opportunities to map the political sensibility of architects, the network of informants activated gained proportions of totalitarian ambitions. The Third International Congress of the International Union of Architects (a nongovernmental organization that had a Portuguese representation) which took place in Lisbon in 1953 is an elucidative case. Since along with other represented countries, there was a group from the Soviet Union, dozens and dozens of informant reports were sent to political police, thoroughly describing the situations where this one or that one architect made contact with any of the Russian members.

As a class, we can hardly or very rarely consider architects as a socio-professional opposition group to the New State. Architects Union was, indeed, very careful not to dress for its battles with ideological garb. Although the number of dissidents clearly grow in the Union's board after the end of the Second World War, thus reflecting the overall strengthening of the regime resistance, the goal was to reach all the class and, above all, to fight for architecture, for the recognition of the profession and the specificity of their function in buildings design.

\footnotetext{
31 PVDE (Polícia de Vigilância e Defesa do Estado-State Defence and Surveillance Police) was formed in August 1933 through the merger and restructuring of previous police forces. It was transformed in PIDE (Polícia Internacional de Defesa do Estado-International Police for the Defense of the State) in 1945 and in DGS (Direcção Geral de Segurança-Directorate of General Security) in 1969.

${ }^{32}$ For a further discussion of this subject see: Ribeiro, 1995; Delgado, 1998; Pimentel, 2007 and Rosas, 2009.

33 Portuguese National Statistics Institute, IX Recenseamento Geral da População no Continente e Ilhas Adjacentes em 15 de Dezembro de 1950 [IX General Population Census in the mainland and adjacent islands on December 15th, 1950], Lisboa, Bertrand Irmãos, 1953.
} 
On the other hand, as individuals, we find architects across all the opposition's initiatives and strategies, especially observable after 1945. They subscribed what was labelled as "subversive and anti-national" pamphlets, such as petitions demanding peace, the freedom of political prisoners, the dismissal of Salazar, the demand of censorship end or the support of campaigns of democratic figures ${ }^{34}$. Signing a petition had serious consequences. The subscriber was immediately considered "politically suspicious" or even "disaffected". Consequently its "moral and political" profile was investigated, searches and long police questionings would take place $^{35}$. Furthermore, this information — the fact that he or she subscribed that petition-would thenceforth be on his/her's individual police record, damaging the chances of becoming a member of an organization board, entering or advance in a public career. Cases of architects forbidden to teach in university schools of arts because of this kind of subscriptions are well known ${ }^{36}$.

One can also find articles signed by architects in clandestine newsletters (for example, the communist Avante! $)^{37}$ or in magazines that, although not prohibited, became a stage for left-wing cultural opposition, like Seara Nova. Moreover, we come across architects that belonged to groups formally dedicated to cultural dissemination but soon converted in, more or less intense, seedbeds of opposition (Fine Arts University Garden $^{38}$; Cooperative of the Spectator ${ }^{39}$; ÁRVORE-Cooperative of Artistic Activities ${ }^{40}$; National Culture Centre $^{41}$; PRAGMA - Cooperative for Cultural Diffusion and Community Action ${ }^{42}$ ). Their participation in opposition organizations, with a variable level of structuring, is also recorded. From committees to defend the freedom of speech, vote or the liberation of political prisoners ${ }^{43}$, to more or less inclusive opposition platforms, such as the Movement of Democratic Unity (created after the Second World War and soon prohibited by the regime; regardless, remained clandestine and gather a large support, starting with university students), the National Democratic Movement, the Academic Anti-fascist Group, the Electoral Independent Front, the Electoral Commission of Democratic Unity or the Portuguese Communist Party.

\footnotetext{
${ }^{34}$ Torre do Tombo National Archive/Collection of the Portuguese Political Police: Hernâni Guimarães Gandra, SR, file n. ${ }^{\circ}$ 663/46; Alberto José Pessoa, SR, file n. ${ }^{\circ}$ 1282/45, unity 2476; Francisco Keil do Amaral, SR, file n. ${ }^{\circ}$ 5924, unity 2422; Francisco Keil do Amaral, CI (2), file n..$^{\circ}$ 5781, unity 7403; Artur Pires Martins, SR, file n. ${ }^{\circ}$ 2625/59, unity 2952; Nuno Teotónio Pereira, CI (2), file n..$^{\circ} 3823$, unity 7295; Nuno Teotónio Pereira and F. Louça, PC, file n. ${ }^{\circ} 1 / 73$, unity 6352-6353.

${ }^{35}$ See, for example, the case of architects such as Gonçalo Ribeiro Telles, João Maria de Braula Reis, Mario Santana de Menezes and Octávio Lixa Filgueiras, whose questionings were motivated by the signature of a pamphlet against the regime repression services. Torre do Tombo National Archive/Collection of the Portuguese Political Police, Nuno Teotónio Pereira, PC, file n. ${ }^{\circ}$ $588 / 59$, unity 5287 .

36 See, for example, the information exchanged in 1971 between the DGS and the General Directorate of Higher Education and Fine Arts, about the architect Pedro Vieira de Almeida, "in order to be hired as a teacher for the School of Fine Arts of Porto" (translation by the author). Torre do Tombo National Archive/Collection of the Portuguese Political Police, Pedro Vieira de Almeida, E/GT, file n. ${ }^{\circ} 1840$, unity 1465.

37 Torre do Tombo National Archive/Collection of the Portuguese Political Police, Victor Manuel Palla and Carmo, Joaquim Cardoso Bento de Almeida, SR, file n. ${ }^{\circ} 2307 / 45$, unity 2478.

${ }^{38}$ Torre do Tombo National Archive/Collection of the Portuguese Political Police, Francisco Keil do Amaral, SR, file n. ${ }^{\circ} 5924$, unity 2422.

39 Torre do Tombo National Archive/Collection of the Portuguese Political Police, Francisco Keil do Amaral, SR, file n. ${ }^{\circ}$ 5924, unity 2422.

${ }^{40}$ Torre do Tombo National Archive/Collection of the Portuguese Political Police, Ernst Lieblich and Arménio Losa, SR, file n. ${ }^{\circ}$ 1566 , unity 2346.

${ }^{41}$ Torre do Tombo National Archive/Collection of the Portuguese Political Police: Nuno Rodrigo Martins Portas, CI (2), file n. ${ }^{\circ}$ 271, unity 6984; Centro Nacional de Cultura, CI (1), file n. ${ }^{\circ} 4819$, unity 1277.

${ }^{42}$ Torre do Tombo National Archive/Collection of the Portuguese Political Police: Nuno Teotónio Pereira, CI (2), file n. ${ }^{\circ} 3823$, unity 7295; Nuno Teotónio Pereira, PC, file n. ${ }^{\circ} 1077 / 67$, unity 5919-5920 - 2. ${ }^{\circ}$ vol.

${ }_{43}$ Torre do Tombo National Archive/Collection of the Portuguese Political Police: Hernâni Guimarães Gandra, CI (1), file n. ${ }^{\circ}$ 1570, unity 1225; Nuno Teotónio Pereira, E/GT, file n. ${ }^{\circ} 3167$, unity 1486; Nuno Teotónio Pereira, CI (2), file n. ${ }^{\circ} 3823$, unity 7295 ; Nuno Rodrigo Martins Portas, CI (2), file n. ${ }^{\circ} 271$, unity 6984.
} 


\section{Conclusion or Closure Without a Rigid Interpretative Perspective}

Notwithstanding the above panorama characterized, a relatively spread thesis that argues that left-wing architects were severely excluded and punished by New State should be questioned. Salazarism did not just tolerate these architects. They were handpicked for designing very often, even though they were recognized as oppositionists. Ideological discrimination could be selective: the same architect might be prevented from teaching (given the danger of "contaminate" the young minds) and, at the same time, be invited to design a public building ${ }^{44}$. An interesting phenomenon is also detected in the relation between the regime and the board of the Architect's Union. Although elected in the general assembly, these members could not assume their position without the authorization of the Ministry of Corporations, which would consult the political police about their moral and ideological profile before deciding. The political police frequently advised against, declaring that this architect "does not offer guarantee of a full cooperation in the fulfillment of the high goals of the State" ${ }^{45}$. However, surprisingly (or not) the minister of Corporations would still give his permission ${ }^{46}$. The law gave him the legitimacy to appoint a Board himself ${ }^{47}$, but he chose to give them this freedom of maneuver. There is only one case of an architect (Keil do Amaral) removed from office ${ }^{48}$ but his collaboration with public works design remained.

We should bear in mind that architects were an elite: a tiny professional niche (in 1940 there were 215 architects in Portugal, all male, according to the Population Census ${ }^{49}$ ) with a large majority coming from a high social and economic backdrop. Therefore, it was not unusual to come across an opposition architect with family connections with middle and superior ranks of Government employees ${ }^{50}$. Furthermore, family relations or a particular admiration for an artist granted, sometimes, a larger aesthetic permissiveness to more radical proposals $^{51}$ or a clear favouritism in the selection of a particular architect.

In conclusion, Portuguese fascism adopted an inclusive logic, typical of fascisms ${ }^{52}$, both in terms of the

\footnotetext{
${ }_{44}$ Interview with architect Manuel Tainha (1922-2012), held in his studio in Lisbon, on 29th July 2009.

45 Torre do Tombo National Archive/Collection of the Portuguese Political Police, Artur Pires Martins, Bol., file n. ${ }^{\circ}$ 146936, unity 8076 . Translation by the author.

${ }^{46}$ Examples of architects with a negative recommendation from the political police found in their individual information bulletins (Torre do Tombo National Archive/Collection of the Portuguese Political Police) and yet still allowed to incorporate the board of the Architect's Union by the Minister: Nuno Teotónio Pereira; Arménio Taveira Losa; António Lobão Vital; José Rafael Botelho; Artur Pires Martins; Manuel Tainha; Mário Jorge Bruxelas.

${ }^{47}$ Law Decree n. ${ }^{\circ} 26$ 418, Diário do Governo [Government Bulletin], 1st series, n. ${ }^{\circ}$ 60, Lisbon, 13th March 1936, p. 302; Law n. ${ }^{\circ}$ 1936, Diário do Governo [Government Bulletin], 1st series, n. ${ }^{\circ}$ 64, Lisbon, 18th March 1936, pp. 315-316; Law Decree n. 32820 , Diário do Governo [Government Bulletin], 1st series, n. ${ }^{\circ} 113$, 2nd June 1943, p. 343.

${ }_{48}$ Boletim do Instituto Nacional do Trabalho e Previdencia [Bulletin of the National Institute of Labour and Welfare], Lisboa, 15th September 1949, p. 340.

${ }_{49}$ Portuguese National Statistics Institute, VIII Recenseamento Geral da População no Continente e Ilhas Adjacentes em 12 de Dezembro de 1940 [VIII General Population Census in the mainland and adjacent islands on December 12th, 1940], Lisboa, Imprensa Nacional de Lisboa, 1945, pp. 20-21, 443.

50 The existence of these personal relations can be detected in the description of several individual information bulletins of architects (organized by the political police) recognized as dissidents. Torre do Tombo National Archive/Collection of the Portuguese Political Police: Boletim de informação n. ${ }^{\circ} 159911$ - Celestino Joaquim de Abreu Castro, CI (1), file n. ${ }^{\circ} 817$, unity 1202; Nuno Teotónio Pereira, Bol., file n. ${ }^{\circ}$ 99390, unity 8028; Nuno Rodrigo Martins Portas, Bol., file n. ${ }^{\circ}$ 170341, unity 8100; José Rafael Santos Nunes Botelho, Bol., file n. ${ }^{\circ} 81586$, unity 8011.

${ }_{51}$ Directive by the Minister of Public Works, Eduardo Arantes e Oliveira, about the design of a bank agency for Coruche (architect José Gomes Bastos). November, 1956. Historical Archive of Caixa Geral de Depósitos, Construction and repair of buildings: agencies outside districts- box n. ${ }^{\circ} 10$, file $n .^{\circ} 72$ (Coruche).

${ }^{52}$ For a further discussion of this subject see: Lane, 1985; Mosse, 1990; Osborne, 1995; Braun, 1995; Llorente Hernández, 1995; Fritzsche, 1996; Stone, 1997; Gentile, 1997; Strathausen, 1999; Koepnick, 1999; Adamson, 2001; Gentile, 2003; Schmid, 2005; Huener \& Nicósia, 2006; Griffin, 2007.
} 
political and ideological positioning of the architects hired, and at the level of the aesthetic languages adopted. Radicalisms — of a political or aesthetics nature — were hard to manipulate. Everything else just depended on the right amount of flexibility and the weighing of the advantages and disadvantages of its inclusion. This logic of negotiation and compromise, which one can verify towards architects, can also be found in the decision process at economic, political or social levels, and it is the key to understand the longevity of the Portuguese fascism.

\section{References}

Acciaiuoli, M. (1991). Os anos 40 em Portugal: o país, o regime e as artes. «Restauração» e «celebração» (The 40's in Portugal: The country, the regime and the arts. «Restoration» and «celebration») (Unpublished doctoral thesis). Lisboa: Universidade Nova de Lisboa.

Adamson, W. (2001). Avant-garde modernism and Italian fascism: Cultural politics in the era of Mussolini. Journal of Modern Italian Studies, 6, 230-248.

Adamson, W. (2001). Avant-garde modernism and Italian fascism: Cultural politics in the era of Mussolini. Journal of Modern Italian Studies, 6, 230-248.

Alçada, M., \& Grilo, M. (1999). Caminhos do património (Heritage paths). Lisboa: DGEMN.

Almeida, P. V. (2002). A arquitectura no Estado Novo: uma leitura critica. Os Concursos de Sagres (The architecture in the New State: A critical reading. The Sagres contests). Lisboa: Livros Horizonte.

Almeida, P. V., \& Fernandes, J. M. (1986). História da arte em Portugal (Art history in Portugal). Lisboa: Alfa.

Alves, V. (2013). Arte popular e nação no Estado Novo: a política folclorista do Secretariado da Propaganda Nacional (Folk art and Nation in the New State: The folkloric policy of the Secretariat of National Propaganda). Lisboa: Imprensa de Ciências Sociais.

Boletim do Instituto Nacional do Trabalho e Previdência [Bulletin of the National Institute of Labour and Welfare], Lisboa, 15th September 1949, p. 340.

Braun, E. (1995). Speaking volumes: Giorgio Morandi's still lifes and the cultural politics of strapaese. Modernism/Modernity, 2, 89-116.

Brites, J. (2014a). O capital da arquitectura. Estado Novo, arquitectos e Caixa Geral de Depósitos (1929-1970) (The capital of architecture. New State, architects and Caixa Geral de Depósitos (1929-1970)). Lisboa: Prosafeita.

Brites, J. (2014b). Arquitectura da CGD. Filiais e agências da Caixa Geral de Depósitos, Crédito e Previdência (1929-1970) (The architecture of CGD. Branches and agencies of Caixa Geral de Depósitos, Crédito e Previdência [Bank of the State] (1929-1970)). Lisboa: Prosafeita.

Colecção Oficial de Legislação Portuguesa [Official Collection of Portuguese Legislation], 1933-1973.

Collotti, E. (1992). Fascismo, Fascismos (Fascism, fascisms). Lisboa: Editorial Caminho.

Costa, A. (1944). Estilo Português (Portuguese style). Diário da Manhã (Daily Morning), 4573, 3.

Cruz, M. B. (1988). O Partido e o Estado no Salazarismo (The Party and the State in Salazarism). Lisboa: Editorial Presença.

Delgado, I. (1998). O império da vigilância (The surveillance empire). In I. Delgado, C. Pacheco, \& T. Faria (Eds.), Humberto Delgado: As eleições de 58 (Humberto Delgado: 1958 elections) (pp. 215-224). Lisboa: Vega.

Diário do Governo [Government Bulletin], 1st series, 1929-1970.

Entrevistas de António Ferro a Salazar [António Ferro interviews with Salazar]. (2013). Lisboa: Parceria A. M. Pereira.

Fernandes, J. M. (2003). Português suave: Arquitecturas do Estado Novo (Soft Portuguese: Architectures of the New State). Lisboa: IPPAR.

Fernandez, S. (1988). Percurso: arquitectura portuguesa, 1930/1974 (Course: Portuguese architecture, 1930/1974) (2nd ed.). Porto: FAUP.

Ferro, A. (1949). Arte moderna (Modern art). Lisboa: SNI.

Foucault, M. (1979). Discipline and punish: The birth of the prison. New York: Vintage Books.

Foucault, M. (1998). Microfisica do poder (Microphysics of power) (13th ed.). Rio de Janeiro: Graal.

França, J. A. (1974). A arte em Portugal no século XX: 1911-1961 (Art in Portugal in the twentieth century: 1911-1961). Lisboa: Livraria Bertrand.

Fritzsche, P. (1996). Nazi Modern. Modernism/Modernity, 3, 1-22. 
Gentile, E. (1997). The myth of national regeneration in Italy: From modernism avant-garde to fascism. In M. Affron, \& M. Antliff (Eds.), Fascist Visions: Art and ideology in France and Italy (pp. 25-45). Princeton: Princeton University Press.

Gentile, E. (2003). The struggle for modernity: Nationalism, futurism, and fascism. Westport, Conn.: Praeger.

Gil, J. (1995). Salazar: A retórica da invisibilidade (Salazar: The rhetoric of invisibility). Lisboa: Relógio D’Água.

Gomes, S. (2000). A construção da profissionalização dos arquitectos em Portugal: um estudo sociológico (The construction of the professionalization of architects in Portugal: A sociological study). Lisboa: ISCTE.

Griffin, R. (2007). Modernism and fascism: The sense of a beginning under Mussolini and Hitler. Houndmills/New York: Palgrave Macmillan.

Historical Archive of Caixa Geral de Depósitos: Collections "Works plans" and "Construction and repair of buildings".

Huener, J., \& Nicosia, F. (2006). The arts in Nazi Germany: Continuity, conformity, change. New York/Oxford: Berghahn Books. Interview with architect Manuel Tainha (1922-2012), held in his studio in Lisbon, on 29th July 2009.

Isabel, A. (2002). Arquitectos portugueses: 90 anos de vida associativa (1863-1953) (Portuguese architects: 90 years of associate activity (1863-1953)). Porto: FAUP.

Koepnick, L. (1999). Fascist aesthetics revisited. Modernism/Modernity, 6, 51-73.

Lane, B. M. (1985). Architecture and politics in Germany, 1918-1945. Cambridge/London: Harvard University Press.

Linz, J. (2000). Totalitarian and authoritarian regimes. Boulder, CO: Lynne Rienner.

Llorente Hernández, A. (1995). Arte e ideología en el franquismo, 1936-1951 (Art and ideology in the Franco regime, 1936-1951). Madrid: Visor.

Lucena, M. (1995). O regime salazarista e a sua evolução (Salazar's regime and its evolution). Matosinhos: Câmara Municipal de Matosinhos.

Madureira, N. (2002). A economia dos interesses: Portugal entre as guerras (The economy of interests: Portugal between the wars). Lisboa: Livros Horizonte.

Medina, J. (2000). Salazar, Hitler e Franco: Estudos sobre Salazar e a ditadura (Salazar, Hitler and Franco: Studies on Salazar's dictatorship). Lisboa: Livros Horizonte.

Melo, D. (2001). Salazarismo e cultura popular (1933-1958) (Salazarism and popular culture (1933-1958)). Lisboa, Portugal: Imprensa de Ciências Sociais.

Mosse, G. (1990). The political culture of Italian futurism: A general perspective. Journal of Contemporary History, 25, 253-268.

Nolte, E. (1969). Les mouvements fascistes: L'Europe de 1919 à 1945 (Fascist movements: Europe between 1919 and 1945). Paris: Calmann-Lévy.

Nunes, J. P. A. (2002). Tipologias de regimes políticos: Para uma Leitura neo-moderna do Estado Novo e do Nuevo Estado (Typologies of political regimes: For a neo-modern reading of the New State and 'Nuevo Estado'). População e Sociedade (Population and Society), 8, 73-101.

O Estado Novo: Das origens ao fim da autarcia (1926-1959) (New State: From origins to the end of the autarchy (1926-1959)). (1987). Lisboa: Editorial Fragmentos.

O fascismo em Portugal. Actas do colóquio (Fascism in Portugal. Colloquium Proceedings). (1982). Lisboa: A Regra do Jogo.

Ó, J. (1999). Os anos de Ferro: O dispositivo cultural durante a "Política do Espírito", 1933-1949: Ideologia, instituições, agentes e práticas (Ferro's years: The cultural apparatus during the "Politics of the Spirit", 1933-1949: Ideology, institutions, agents and practices). Lisboa: Editorial Estampa.

Osborne, P. (1995). The politics of time: Modernity and avant-garde. London: Verso.

Pereira, N. T., \& Fernandes, J. M. (1981). A arquitectura do fascismo em Portugal (Fascist architecture in Portugal). Arquitectura (Architecture), 142, 38-48.

Pereira, P. (1997). História da arte portuguesa (History of Portuguese art). Lisboa: Círculo de Leitores.

Pernes, F. (1999). Panorama: Arte portuguesa no século XX (Panorama: Portuguese art in the twentieth century). Porto: Fundação Serralves.

Pimentel, I. F. (2007). A História da PIDE (The history of PIDE). Lisboa: Círculo de Leitores/Temas e Debates.

Pinto, A. C. (1992). O Salazarismo e o fascismo europeu: Problemas de interpretação nas ciências sociais (Salazarism and European fascism: Problems of interpretation in the social sciences). Lisboa: Editorial Estampa.

Pinto, A. C. (2001). O império do professor: Salazar e a elite ministerial do Estado Novo (1933-1945) (The empire of the professor: Salazar and the ministerial elite of the New State (1933-1945)). Análise Social (Social Analysis), XXXV(157), $1055-1078$. 
Portas, N. (1973). A evolução da arquitectura moderna em Portugal: uma interpretação (The evolution of modern architecture in Portugal: An interpretation). In B. Zevi (Ed.), História da Arquitectura Moderna (History of Modern Architecture) (pp. 687-744). Lisboa: Editora Arcádia.

Portuguese National Statistics Institute, IX Recenseamento Geral da População no Continente e Ilhas Adjacentes em 15 de Dezembro de 1950 [IX General Population Census in the mainland and adjacent islands on December 15th, 1950], Lisboa, Bertrand Irmãos, 1953.

Portuguese National Statistics Institute, VIII Recenseamento Geral da População no Continente e Ilhas Adjacentes em 12 de Dezembro de 1940 [VIII General Population Census in the mainland and adjacent islands on December 12th, 1940], Lisboa, Imprensa Nacional de Lisboa, 1945.

Ribeiro, M. (1995). A Polícia Politica no Estado Novo: 1926-1945 (The political police in the new State: 1926-1945). Lisboa: Editorial Estampa.

Rosas, F. (1992). As grandes linhas da evolução institucional (The broad lines of institutional development). In F. Rosas (Ed.), Nova História de Portugal (New History of Portugal) (pp. 86-143). Lisboa: Editorial Presença.

Rosas, F. (1993). História de Portugal (History of Portugal). Lisboa: Círculo de Leitores.

Rosas, F. (2001). O salazarismo e o homem novo: Ensaio sobre o Estado Novo e a questão do totalitarismo (The Salazar and the new man: Essay on the New State and the question of totalitarianism). Análise Social (Social Analysis), XXXV(157), 1031-1054.

Rosas, F. (2009). Tribunais políticos: Tribunais Militares Especiais e Tribunais Plenários durante a Ditadura e o Estado Novo (Political courts: Special Military Tribunals and Plenary Courts during the dictatorship and the New State). Lisboa: Temas e Debates/Círculo de Leitores.

Rosmaninho, N. (2006). O poder da arte: o Estado Novo e a Cidade Universitária de Coimbra (The power of art: New State and the university Campus of Coimbra). Coimbra: Imprensa da Universidade.

Salazar, A. (1935). Discursos e notas politicas (Speeches and political notes). Coimbra: Coimbra Ed.

Schmid, U. (2005). Style versus ideology: Towards a conceptualisation of fascist aesthetics. Totalitarian Movements and Political Religions, 6, 127-140.

Stone, M. (1997). The State as patron: Making official culture in fascist Italy. In M. Affron, \& M. Antliff (Eds.), Fascist visions: Art and ideology in France and Italy (pp. 205-238). Princeton: Princeton University Press.

Strathausen, C. (1996). Nazi aesthetics. Culture, Theory and Critique, 42, 5-19.

Torgal, L. R. (1994). Salazarismo, Alemanha e Europa: Discursos políticos e culturais (Salazarism, Germany and Europe: Political and cultural discourses). Revista de História das Ideias (Journal of the History of Ideas), 16, 73-104.

Torre do Tombo National Archive: Collection of the Portuguese Political Police.

Tostões, A. (1997). Os verdes anos na arquitectura portuguesa dos anos 50 (The green years in the Portuguese architecture of the 50's) (2nd ed.). Porto: FAUP.

Tostões, A. (2004). Arquitectura moderna portuguesa: 1920-1970 (Portuguese modern architecture: 1920-1970). Lisboa: IPPAR.

Tostões, A. (2009). Arte portuguesa: Da Pré-História ao século XX (Portuguese art: From prehistory to the twentieth century). Porto: Fubu Editores.

Tostões, A. (2015). A idade maior: Cultura e tecnologia na arquitectura moderna portuguesa (Mature age: Culture and technology in modern Portuguese architecture). Porto: FAUP.

Weber, M. (1978), Os fundamentos da organização burocrática: uma construção do tipo ideal (The foundations of the bureaucratic organization: A construction of the ideal type). In E. Campos (Ed.), Sociologia da Burocracia (Sociology of Bureaucracy) (pp. 15-28). Rio de Janeiro: Zahar Editores. 